\title{
Thalassemia in Israel: 2012
}

\section{Pinhas Stark}

The Comprehensive Center of Thalassemia and Hemoglobinopathies Rabin Medical Center, Beilinson Hospital, Petah Tikva, Israel

\section{Oral presentation}

Oral presentation is available online

Correspondence: Pinhas Stark

CCopyright P. Stark, 2013

Licensee PAGEPress, Italy

Thalassemia Reports 2013; 3(s1):e28

doi:10.4081/thal.2013.s1.e28

This article is distributed under the terms of the Creative Commons Attribution Noncommercial License (by-nc 3.0) which permits any noncommercial use, distribution, and reproduction in any medium, provided the original author(s) and source are credited.

Parts of this work were presented at the

"3rd Pan-European Conference on Haemoglobinopathies and Rare Anaemias", Limassol (Cyprus), 24-26 October 2012. 